\title{
Ultrastructural Localization of 5'AMP Odorant Receptor Sites on the Dendrites of Olfactory Receptor Neurons of the Spiny Lobster
}

\author{
David N. Blaustein, Robert B. Simmons, Michele F. Burgess, Charles D. Derby, Michiko Nishikawa, ${ }^{a}$ and \\ Kirby S. Olson \\ Department of Biology, Georgia State University, Atlanta, Georgia 30302-4010
}

\begin{abstract}
A unique probe-biotinylated adenosine-5'-monophosphate (5'AMP-biotin)-was used in transmission electron microscopic (TEM) studies to localize 5'AMP odorant binding sites on the dendrites of olfactory receptor neurons in the aesthetasc sensilla of the spiny lobster, Panulirus argus. This probe is capable of both binding to and exciting 5'AMP-sensitive olfactory receptor neurons, as revealed through biochemical and electrophysiological assays. TEM studies showed that 5 'AMP-biotin binding sites are distributed along the entire dendritic region that is exposed to odorants, including the transitional zone (between the inner and outer dendritic segments, including the ciliary segment) and all of the outer dendritic segment. The density of 5'AMP binding sites per $\mu \mathrm{m}^{2}$ of membrane is similar along the length of the olfactory dendrite. However, the relative number of 5'AMP-biotin binding sites per $\mu \mathrm{m}^{2}$ of sensillar area diminishes in the distal $30 \%$ of the aesthetasc due to a decrease in the amount of dendritic membrane in that region. The distribution of these 5 'AMP binding sites is therefore much more extensive than that of enzymes that inactivate 5' AMP-5'ectonucleotidase/ phosphatase-which are restricted to the transitional zone (Gleeson et al., 1991). Taken together, these results suggest that 5'AMP-biotin is labeling 5'AMP-specific olfactory receptor sites that are located along the entire outer dendritic segment and that can be coupled to olfactory transduction. This study represents the first in situ localization of specific olfactory receptor sites using a specific, functionally defined ligand.
\end{abstract}

[Key words: aesthetasc sensilla, biotinylated probe, chemoreception, binding, Panulirus argus, transmission electron microscopy]

Olfactory receptor neurons of most vertebrates and arthropods (crustaceans, insects, arachnids) are modified ciliary cells, of which the distal membrane is exposed to the external environ-

\footnotetext{
Received Oct. 28, 1992; revised Jan. 14, 1993; accepted Jan. 18, 1993

This research was supported by NIDCD Grants R01 DC00312 and K04 DC00002. We thank John Swanson and Bill Gibbs of the Florida Keys Regional Marine Laboratory for collection of lobsters; Willert H. Lynn for superb technical assistance; Dr. Chandrasekaran for performing the $\mathrm{H}^{\prime}$ NMR and mass spectrometry studies; M. Lynn Milstead for providing Figure 1 and the inset of Figure $7 A$; Drs. Bill Carr, Rick Gleeson, Hank Trapido-Rosenthal, and Debhie Wood for helpful discussions; and Dr. Bill Walthall for his critical reading of the manuscript and his valuable suggestions.

Correspondence should be addressed to Dr. David Blaustein, Department of

Biology, Georgia State University, P.O. Box 4010, Atlanta, GA 30302-4010.

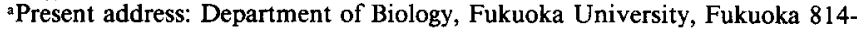

01. Japan.

Copyright (c) 1993 Society for Neuroscience $0270-6474 / 93 / 132821-08 \$ 05.00 / 0$
}

ment. In the ciliary olfactory neurons of vertebrates, this distal membrane consists of an apical dendrite (= olfactory knob) and cilia (Menco, 1983; Burton, 1992; Menco et al., 1992); in arthropods, the distal membrane consists of an outer dendritic segment and, in some species, a ciliary segment and a part of the inner dendritic segment as well (Menco and van der Wolk, 1982; Spencer and Linberg, 1986; Tierney et al., 1986; Grünert and Ache, 1988; Hallberg et al., 1992; Keil, 1992). There is general agreement that this distal membrane of olfactory receptor neurons contains many of the olfactory transduction components, including rcceptor molecules, G-proteins, enzymes involved in the production of second messengers (e.g., adenylate cyclase and phospholipase (C), and cyclic nucleotide-gated or inositol triphosphate $\left(\mathrm{IP}_{3}\right.$ )-gated ion channels (Anholt, 1991; Asanuma and Nomura, 1991; Gleeson et al., 1991, 1992; Kinnamon and Getchell, 1991; Kurahashi and Kaneto, 1991; Zufall and Hatt, 1991; Fadool and Ache, 1992; Menco et al., 1992; Miyamoto et al., 1992; Olson et al., 1992). However, several questions concerning the location of these transduction molecules remain, for which only partial answers are available. Are these molecules located on both the ciliary and nonciliary regions of the distal membrane? Some have argued that within several vertebrate species it is the apical dendrite and the proximal part of the cilia of vertebrate olfactory receptor neurons that are mainly involved in olfactory transduction (Ottoson and Shepherd, 1967; Getchell et al., 1980). However, more recent electrophysiological, biochemical, and anatomical evidence suggests that the odorant receptor molecules as well as other components of the transduction mechanism most involved in olfactory transduction are principally located on the cilia and not on the apical dendrites (e.g., Kinnamon and Getchell, 1991; Lowe and Gold, 1991). Is each type of transduction molecule equally distributed along the entire length of the distal membrane? Based on electrophysiological evidence, Lowe and Gold (1991) concluded that odorant receptor molecules and other transduction components are uniformly distributed along the cilia. In an effort to localize and describe the distribution of possible transduction molecules at the ultrastructural level, Menco and colleagues (Menco et al., 1976; Menco and van der Wolk, 1982; Menco, 1983) used freeze-fracture techniques with transmission electron microscopy (TEM) to visualize intramembranous particles on olfactory neurons of vertebrates and insects. These particles are present over the entire sensory surface of dendrites, but they are much more numerous on the distal ends of the cilia than on the proximal ends or on the apical dendrite. These particles are less common on the ciliary membranes of nonsensory cells. These authors suggest that these particles are membrane proteins such as receptor molecules or ion channels, but their exact 


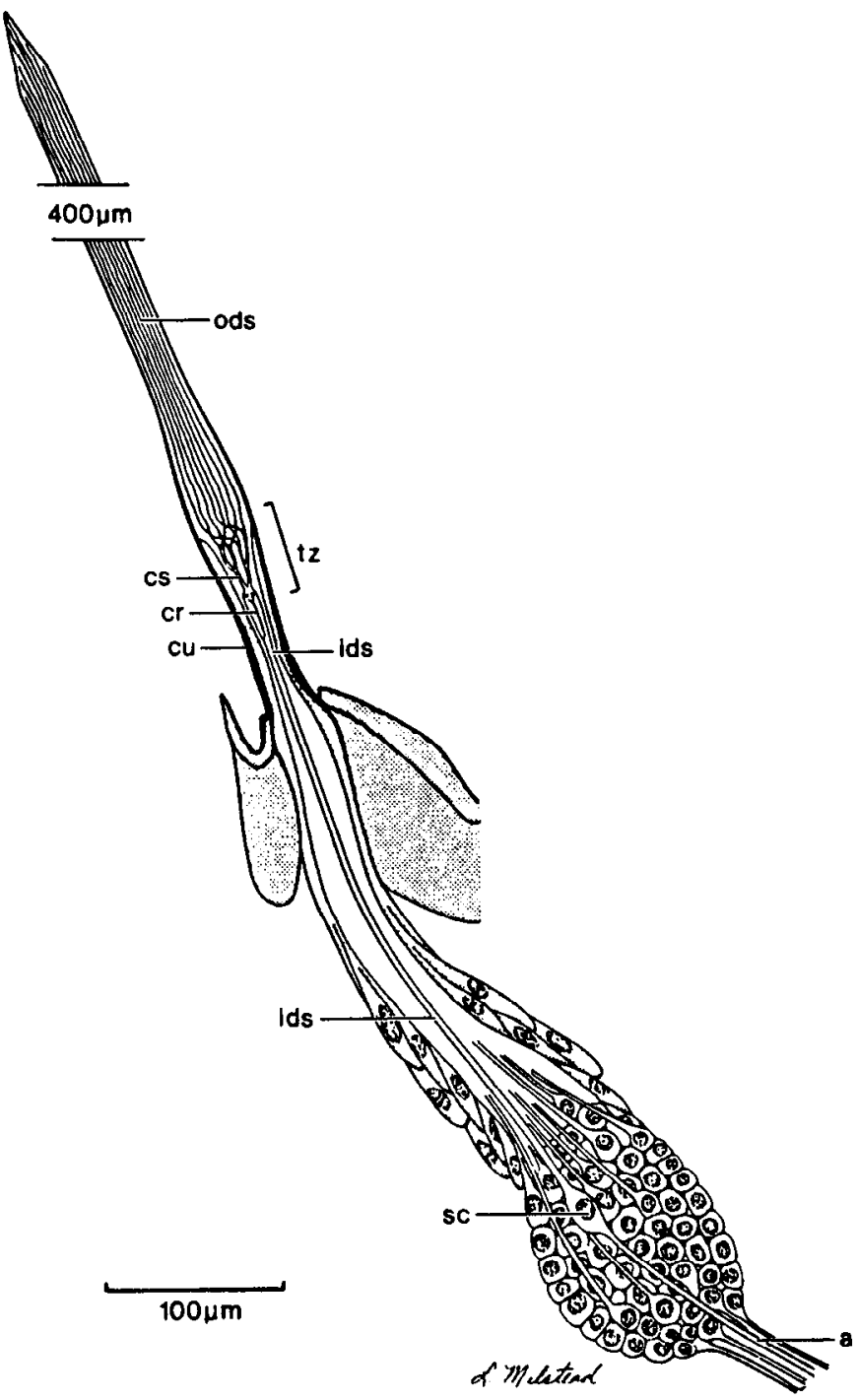

Figure 1. Aesthetasc sensillum and its olfactory receptor neurons. $a$, Axons; $c r$, ciliary rootlet; $c s$, ciliary segment; $c u$, cuticle; ids, inner dendritic segment; ods, outer dendritic segment; $s c$, sensory cell soma; $t z$ transitional zone (modified from Grünert and Ache, 1988).

identity is uncertain. More recently, Menco et al. (1992), using TEM immunocytochemistry, have found that $\mathrm{G}_{\mathrm{olf} \alpha}$ and type III adenylate cyclase are mainly found in the long distal parts of the cilia of rat olfactory neurons. What is the distribution of the receptor molecules relative to other transduction molecules? Membrane-bound, odorant-degrading enzymes have a very restricted distribution on the olfactory receptor neuron dendrites of spiny lobsters, being limited to the transitional zone between the inner and outer dendritic segments (Gleeson et al., 1991, 1992). But the distribution of receptor molecules remains unknown.

Anatomical localization of odorant-specific receptor molecules on olfactory neurons has been problematic because specific ligands that serve as anatomical markers have not been available. In our study, we have sought to overcome this problem by developing and using a specific ligand-adenosine- $5^{\prime}$-monophosphate (5'AMP) conjugated to biotin - in TEM immunocytochemical studies to localize 5'AMP olfactory receptor molecules to regions of the olfactory receptor neurons in the olfactory organ of the spiny lobster Panulirus argus. The 5'AMP receptor system was chosen because it has previously been well characterized in electrophysiological (Derby et al., 1984, 1991a,b), biochemical (Trapido-Rosenthal et al., 1987, 1990; Carr et al., 1990; Olson et al., 1992), and behavioral (Fine-Levy and Derby, 1992) studies. The olfactory organ of $P$. argus is the lateral filament of the antennule, which contains approximately 1500 aesthetasc sensilla. Grünert and Ache (1988) have provided a detailed anatomical and ultrastructural description of the aesthetasc sensillum of $P$. argus. Each sensillum is $750-850 \mu \mathrm{m}$ in length and is innervated by approximately 320 bipolar olfactory receptor neurons. Each bipolar neuron consists of an inner dendritic segment (IDS), a ciliary segment (CS), and an outer dendritic segment (ODS) (Fig. 1). The IDS contains microtubules, mitochondria, and a ciliary rootlet that originates from two basal bodies of $9 \times 3$ microtubular construction. Within a short transitional zone (TZ) (ca. $50 \mu \mathrm{m}$ ), each basal body gives rise to the CS, which has a "ciliary necklace"-like structure and a $9 \times 2+2$ microtubular organization. Each CS gives rise to the ODS, which branches extensively and dichotomously, subsequently losing its axonemic structure as it extends into the distal end of the sensillum. As a result, each olfactory neuron has 20-30 ODS branches, and each sensillum has 8000-10,000 ODS branches. Our present study shows that 5'AMP-biotin binds to a population of sites present at similar densities along the entire region of the dendrite that is exposed to odorants; however, the number of binding sites decreases in the distal 30\% of the ODS since this region contains relatively less dendritic membrane. Correlative biochemical and electrophysiological studies suggest that 5'AMP-biotin is labeling 5'AMP-specific olfactory receptor sites that can be coupled to transduction. In addition, the distribution of these 5'AMP odorant receptor sites is different from that previously described for ectoenzymes that inactivate 5'AMP (Gleeson et al., 1991).

\section{Materials and Methods}

Animals. Spiny lobsters (Panulirus argus), collected in the Florida Keys, were held in seawater aquaria at approximately $23^{\circ} \mathrm{C}$. All animals utilized were intermolt and of $40-50 \mathrm{~mm}$ carapace length.

The biotinylated 5'AMP probe. The structure-activity relationship for adenosine- $5^{\prime}$-monophosphate ( $5^{\prime}$ AMP) as a chemical stimulant for crustacean 5'AMP olfactory receptors was previously established by comparing the relative physiological and behavioral activities of 5'AMP with 17 of its structural analogs (Derby et al., 1984). Of all the analogs tested, 6-chloropurine riboside- $5^{\prime}$-monophosphate (6-CPR) maintained the highest activity as both an electrophysiological excitant and a behavioral attractant-approximately $60 \%$ that of 5'AMP. Since biotinylated purine nucleotides have been used successfully for detecting and labeling DNA (Klevan and Gebeyehu, 1990), for histochemically localizing receptor proteins (Stiles, 1986), and for assaying extracellular adenosine receptor sites via competitive binding studies in mammalian tissue (Jacobson et al., 1990), we chose to use a biotinylated purine nucleotide to label 5'AMP sites in TEM studies. Our probe was 6-CPR to which biotin was substituted at the $\mathrm{C} 6$ position via a linker arm. Chlorinated aromatic substituents of molecules readily undergo nucleophilic substitution reactions, permitting the restoration of the 5'AMP amino group at $\mathrm{C} 6$ of the purine double ring. Cadaverine, a 1,5-diaminopentane, was utilized as a linker between biotin and 6-CPR, forming a stable 5'AMP-biotin probe (Fig. 2). The synthesis of the probe was carried out by Molecular Probes, Inc. (Eugene, OR). To verify the synthesis and determine the purity of the molecule, $\mathrm{H}^{\prime}$ NMR spectra were obtained in a Varian VXR-400 $(400 \mathrm{MHz})$ instrument at $25^{\circ} \mathrm{C}$ in $\mathrm{D}_{2} \mathrm{O}$ solution with tetramethylsilane as an internal standard. The purity of the $5^{\prime} \wedge$ MP-biotin was greater than $99.99 \%$. The molecular weight was confirmed using fast atomic bombardment mass spectrometry.

Biochemical assay of binding of 5 'AMP-biotin to olfactory membrane. To evaluate the ability of 5'AMP-biotin to bind specifically to dendrites 
of olfactory receptor neurons, we used a biochemical assay (Olson et al., 1992), as briefly described here. Aesthetasc sensilla were collected and placed in an $\mathrm{Na}^{+}$-free Tris buffer. Homogenization, sonication, and centrifugation of this tissue produced a P2 tissue fraction that was highly enriched in dendritic membrane from olfactory receptor neurons. The biochemical assay consisted of incubating the P2 fraction with $1 \mu \mathrm{M}$ ${ }^{3} \mathrm{H}$-adenosine-5'-monophosphate (specific activity, $29.0 \mathrm{Ci} / \mathrm{mmol}$; DuPont-New England Nuclear) at $4^{\circ} \mathrm{C}$ for 60 min. Filtration was used to separate bound from free ${ }^{3} \mathrm{H}-5$ 'AMP. Total binding and nonspecific binding were characterized by incubation of ${ }^{3} \mathrm{H}-5^{\prime} \mathrm{AMP}$ in the absence or presence, respectively, of $1 \mathrm{~mm}$ unlabeled 5'AMP. Specific binding was defined as the difference between total binding and nonspecific binding. In competition experiments, P2 tissue was incubated in $1 \mu \mathrm{M}$ ${ }^{3} \mathrm{H}-5^{\prime} \mathrm{AMP}$ and varying concentrations $\left(10^{-8}\right.$ to $\left.10^{-3} \mathrm{M}\right)$ of unlabeled $5^{\prime}$ AMP or 5'AMP-biotin, or $10^{-4} \mathrm{M}$ biotin. In the "split hair" biochemical experiments, antennules were placed in buffer; the distal halves of the aesthetasc sensilla were removed by cutting with fine scissors and were collected in the buffer; the proximal halves of these same sensilla were then collected separately by scraping them from the antennule using a scalpel blade.

Electrophysiological assay of sensitivity of olfactory receptor neurons to 5'AMP-biotin. To determine if 5'AMP-biotin excites 5'AMP-sensitive olfactory receptor neurons, we recorded electrophysiological responses from eight 5'AMP-sensitive neurons using an excised lateral antennular preparation (described more fully in Derby et al., 1984). The proximal end of the antennule was isolated from the distal end by inserting it into a separate recording chamber containing Panulirus saline. The antennular nerve and artery were exposed by dissection, and the artery was cannulated and perfused with oxygenated saline at a flow rate of $1-3 \mathrm{ml} / \mathrm{min}$. The distal end of the excised antennule was located in a Teflon tube attached to an olfactometer in which artificial seawater (ASW) flowed at a velocity of $9 \mathrm{~cm} / \mathrm{sec}$. Activation of a valve in the olfactometer injected a $6 \mathrm{sec}$ constant pulse of stimulus into the ASW flow. Extracellular recordings of spiking activity of single neurons in the antennular nerve were made en passant using fine-tipped suction electrodes. The experimental protocol consisted of recording from 5'AMPsensitive neurons, which were identified by their altered firing rates in response to a search stimulus of $100 \mu \mathrm{M} 5^{\prime}$ AMP. Responses were then recorded to the following stimuli, presented randomly every 2-3 min: 10 and $1 \mu \mathrm{M}$ 5'AMP, 10 and $1 \mu \mathrm{M}$ 5'AMP-biotin, and ASW. Responses were measured as the number of spikes generated by a stimulus during the $5 \mathrm{sec}$ period following initiation of the response, which occurred approximately $1 \mathrm{sec}$ after stimulus introduction. This delay between stimulus introduction and initiation of the $5 \mathrm{sec}$ counting period was held constant for all stimulations of a single neuron. Responses were corrected for spontaneous spiking rate. (The spontaneous spiking rate for these eight neurons was $0.9 \pm 0.5 \mathrm{~Hz}$, mean \pm SEM.) Finally, responses were standardized for each neuron by expressing each response as a percentage of the response to $10 \mu \mathrm{M} 5^{\prime} \mathrm{AMP}$.

Iransmission electron microscopic immunocytochemistry. Intact lateral antennular filaments of intermolt animals were exposed for $0.5 \mathrm{~min}$ to one of three conditions to determine (1) total 5'AMP-biotin binding, (2) nonspecific 5'AMP-biotin binding, and (3) endogenous biotin-like immunoreactivity. These three conditions were (1) $1.24 \times 10^{-5} \mathrm{M} 5^{\prime} \mathrm{AMP}$ biotin in $P$. argus saline, (2) $1.24 \times 10^{-5} \mathrm{M} 5^{\prime}$ AMP-biotin $+1.24 \times$ $10^{-3} \mathrm{M}$ unlabeled $5^{\prime}$ AMP in $P$. argus saline, and (3) $P$. argus saline, respectively. 5'AMP-biotin-specific binding was calculated as the difference between total binding (condition 1) and nonspecific binding (condition 2). After exposing the tissue to one of these conditions, the intact antennule was placed in a primary fixative of $0.5 \%$ acrolein, $2.5 \%$ glutaraldehyde, $15 \%$ sucrose, and $1 \mathrm{~mm} \mathrm{MgCl} \mathrm{m}_{2}$ in 0.1 M Sörensen buffer (pH 7.4) for $0.5 \mathrm{~min}$ at room temperature. The antennule was then dissected from the animal and placed in a secondary fixative of $2.5 \%$ glutaraldehyde, $15 \%$ sucrose, and $1 \mathrm{~mm} \mathrm{MgCl}_{2}$ in 0.1 M Sörensen buffer for $2 \mathrm{hr}$ at $4^{\circ} \mathrm{C}$. The antennule was then dissected into two-annuli sections, rinsed in Sörensen buffer six times for $10 \mathrm{~min}$ each, dehydrated in a graded alcohol series up to $90 \%$ ethanol, and embedded in LR Gold resin (London Resin Co., Basingstokes, UK). The resin was polymerized under ultraviolet light $\left(366 \mathrm{~nm}\right.$ ) at $4^{\circ} \mathrm{C}$ for $24 \mathrm{hr}$ using $0.1 \%$ benzoin methyl ether as the cross-linking agent.

Immunocytochemical localization of biotin was carried out on 90nm-thick sections mounted on Formvar-coated nickel grids. Cross sections and longitudinal sections were taken from the transitional zone and from regions along the entire length of the outer dendritic segment. Seclions were incubated in $5 \%$ normal donkey serum $+0.1 \%$ protease-

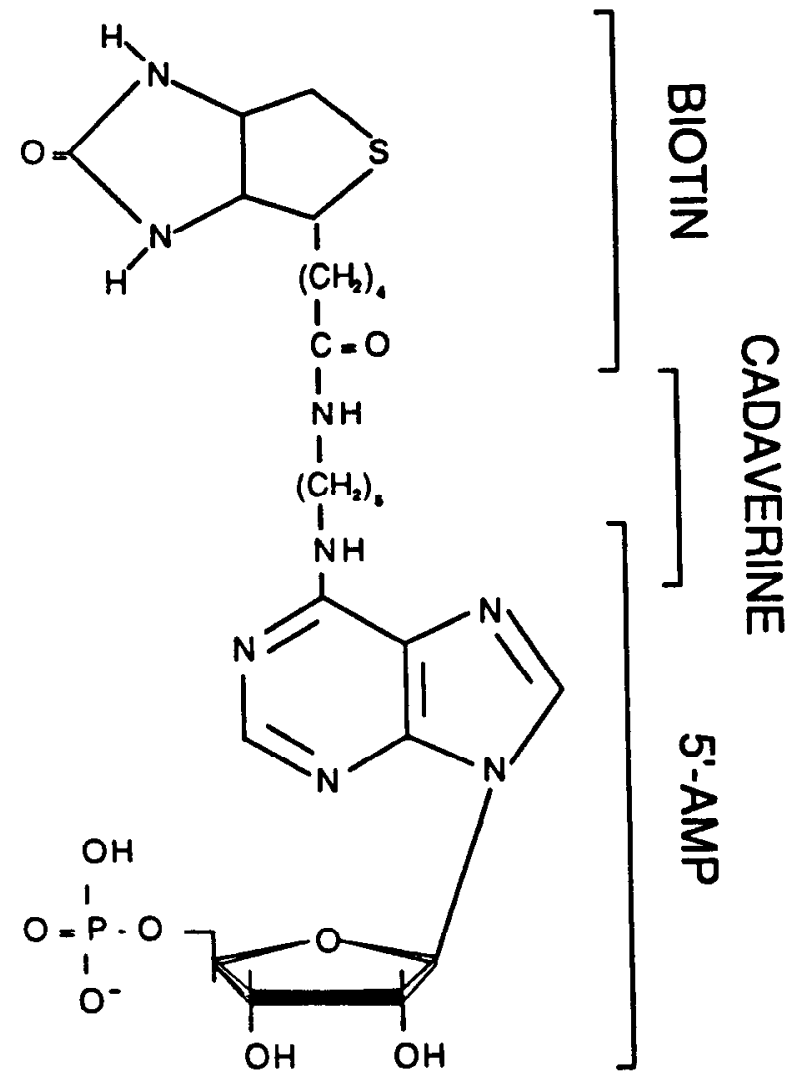

Figure 2. The molecular structure of biotinylated 5'AMP.

free bovine serum albumin (BSA) (Sigma Chemical Co.) in phosphatebuffered saline with pH of 7.8 (PBS) for $10 \mathrm{~min}$ at room temperature, and rinsed with PBS for $1 \mathrm{~min}$. They were then incubated in monoclonal (IgG1) mouse anti-biotin antibody (Dako) at a dilution of 1:75 in PBS $+0.1 \%$ protease-free BSA at $4^{\circ} \mathrm{C}$ for $12-16 \mathrm{hr}$ overnight, and subsequently rinsed with PBS for $1 \mathrm{~min}$. Sections were then incubated in donkey anti-mouse antibody conjugated to $18 \mathrm{~nm}$ gold particles (Jackson ImmunoResearch Laboratories, Inc.) at a dilution of 1:150 in PBS $+0.1 \%$ protease-free BSA for $1 \mathrm{hr}$ at room temperature, and afterward rinsed with PBS for $1 \mathrm{~min}$ followed by a rinse with deionized water for $15 \mathrm{sec}$. The sections were stained with filtered $1 \%$ uranyl acetate for $15-$ $20 \mathrm{~min}$ at room temperature, and then rinsed with deionized water for 1 min. Grids were allowed to air dry and were viewed with a JEOL JEM-100 CX II transmission electron microscope operating at an accelerating voltage of $80 \mathrm{kV}$

Determination of the amount of dendritic membrane within different regions of the aesthetasc sensilla (i.e., $\mu \mathrm{m}^{2}$ of membrane per $\mu \mathrm{m}^{2}$ area within the sensillum) was carried out via evaluation of sensilla cut in cross section. Eight to twelve percent of the total cross-sectional area within a sensillum was randomly sampled, and the area of dendritic membrane within each of five sensillar regions [transitional zone (TZ), ODS1, ODS2, ODS3, and ODS4; see Fig. $7 A$, inset] was determined from 10 sensilla. The average amount of membrane within a given area of sensillum was determined for each sensillar region in the following way. The area of membrane for each cross-sectioned dendrite was determined from the equation $\pi \cdot d \cdot w$, where $d$ is diameter of dendrite $(\mu \mathrm{m})$ and $w$ is width of membrane $(0.015 \mu \mathrm{m})$. These membrane areas were summed and divided by the sensillar area from which they were sampled, resulting in the amount $\left(\mu \mathrm{m}^{2}\right)$ of dendritic membrane per $\mu \mathrm{m}^{2}$ of sensillar area.

\section{Results}

$5^{\prime} A M P$-biotin is an agonist for the 5'AMP site on olfactory receptor neurons

To determine if the biotinylated 5'AMP probe binds specifically to 5'AMP binding sites on dendrites of olfactory receptor neu- 


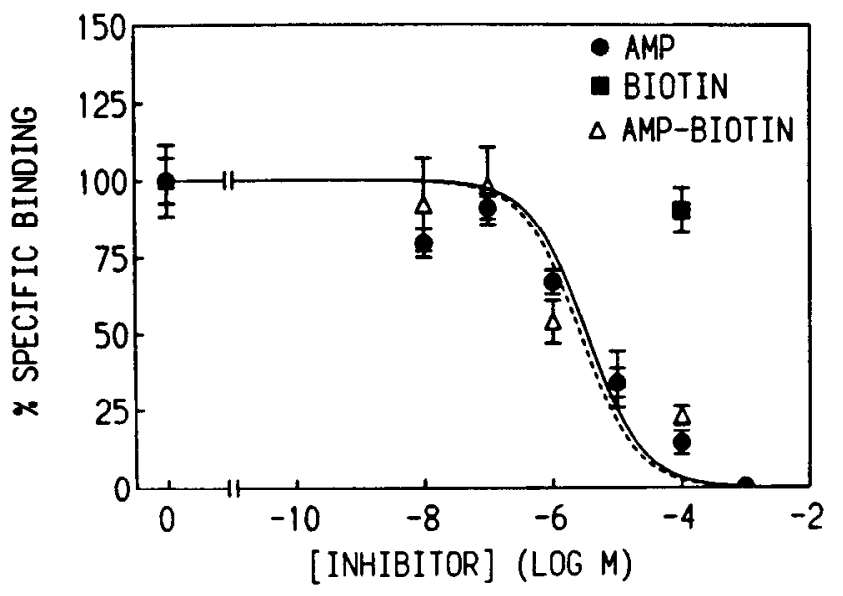

Figure 3. Inhibition of ${ }^{3} \mathrm{H}-5^{\prime} \mathrm{AMP}$ binding by $5^{\prime} \mathrm{AMP}-$ biotin. The $\mathrm{P} 2$ tissue fraction was incubated with $1 \mu \mathrm{M}{ }^{3} \mathrm{H}-5$ 'AMP alone or with $1 \mu \mathrm{M}$ ${ }^{3} \mathrm{H}-5$ 'AMP plus varying concentrations of unlabeled 5'AMP (solid circles), 5'AMP-biotin (open triangles), or $100 \mu \mathrm{M}$ biotin (solid square). Values from each experiment were normalized to the maximum value for that experiment, as represented by $100 \%$. Values represent means \pm SEM for two experiments, each run in triplicate. The inhibition curves for 5'AMP and 5'AMP-biotin are not different [ANOVA, $F(1,26)=$ $0.0037, P=0.91$; using the linear, dynamic portion of the curves].

rons, competitive inhibition binding biochemical studies were carried out (Fig. 3). Incubation of P2 tissue fraction and $1 \mu \mathrm{M}$ ${ }^{3} \mathrm{H}-5$ 'AMP with increasing concentrations of either unlabeled 5'AMP or 5'AMP-biotin resulted in a similar degree of statistically significant inhibition, with $\mathrm{IC}_{50}$ values for 5'AMP and 5'AMP-biotin being $3.4 \mu \mathrm{M}$ and $2.1 \mu \mathrm{M}$, respectively. Conversely, $100 \mu \mathrm{M}$ biotin did not significantly inhibit binding of ${ }^{3} \mathrm{H}$ 5'AMP. Thus, neither the cadaverine nor biotin moieties of the

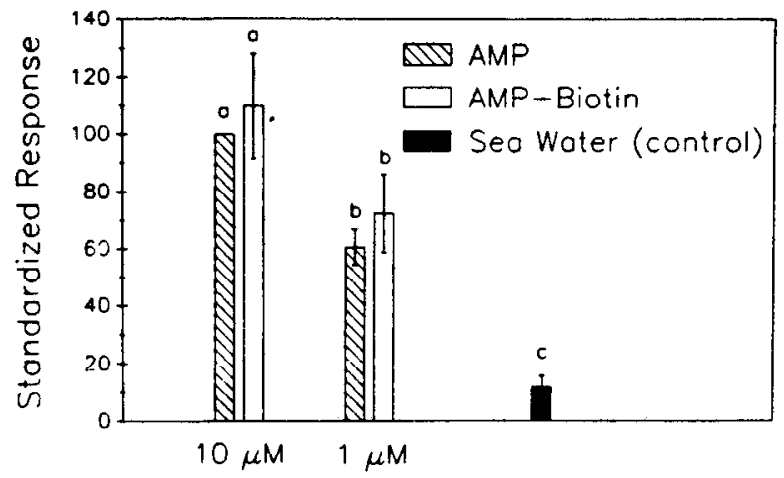

Figure 4. Electrophysiological responses of 5'AMP-sensitive olfactory receptor neurons to 5'AMP-biotin. Standardized responses are expressed as a percentage of the response to $10 \mu \mathrm{M} 5^{\prime} \mathrm{AMP}$. Values are the means \pm SEM for eight neurons. Responses that are significantly different are labeled with different letters $(a-c)$, while responses that arc not significantly different are labeled with the same letter (ANOVA and Student-Newman-Keuls multiple comparisons test, $\alpha=0.05$ ).

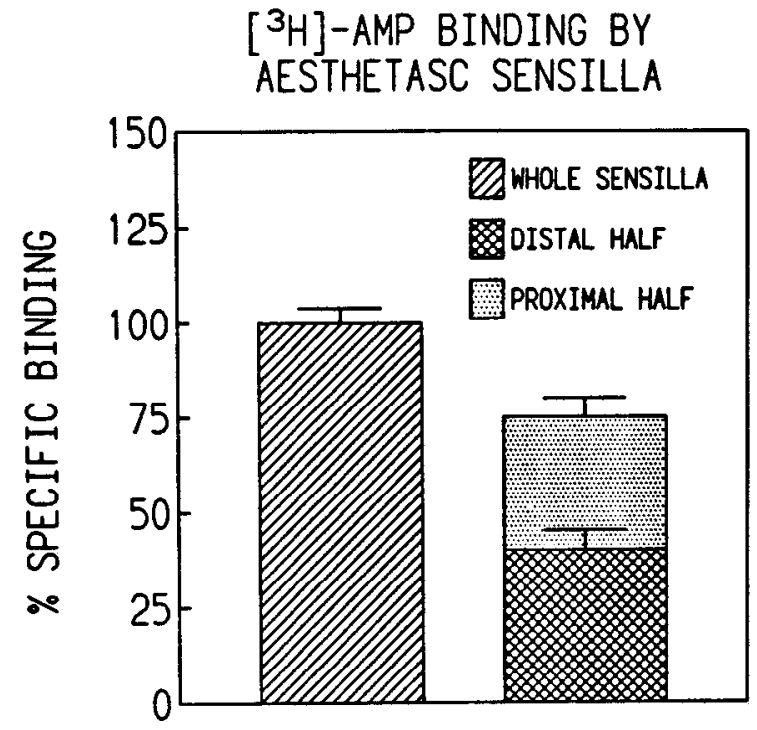

Figure 5. Biochemical evaluation of the proportion of ${ }^{3} \mathrm{H}-5^{\prime} \mathrm{AMP}-$ specific binding sites in the distal and proximal halves of aesthetasc sensilla. Values from each experiment were normalized to the maximum value for that experiment, represented by $100 \%$. Values are means \pm SEM from two experiments, each run in triplicate. Values for the distal half and proximal half are not significantly different from each other $(t$ test, $P>0.05$ ).

5'AMP-biotin probe interfered with the interaction of 5'AMP with its binding sites on dendritic membranes of olfactory receptor neurons.

To test the efficacy of 5'AMP-biotin as an olfactory receptor probe, electrophysiological responses of eight 5'AMP-sensitive olfactory receptor neurons were recorded using 5'AMP and 5'AMP-biotin as experimental stimuli and ASW as a control (Fig. 4). The responses to 5'AMP and to 5'AMP-biotin were not significantly different from each other, at either 10 or $1 \mu \mathrm{M}$; however, both were significantly greater than the response to the ASW control. Therefore, addition of cadaverine-biotin at C6 of the purine base appears to have little effect on the ability of 5'AMP to excite 5'AMP-sensitive olfactory receptor neurons.

\section{The distribution of 5'AMP-biotin binding sites}

Biochemistry. To determine if 5'AMP binding sites are present in both the distal and proximal portions of the aesthetasc sensilla, the biochemical binding assay was used. In this "splithair" experiment, specific binding of ${ }^{3} \mathrm{H}-5$ 'AMP was compared from P2 fractions prepared from three tissues: (1) the entire sensillum, which contains the distal portion of the IDS, CS, TZ, and ODS; (2) the distal half of the sensillum, which contains approximately the distal $60 \%$ of the ODS; and (3) the proximal half of the sensillum, which contains the IDS, CS, TZ, and approximately the proximal $40 \%$ of the ODS. Both distal and proximal halves displayed significant and equal 5'AMP-specific

Figure 6. Distribution of $5^{\prime}$ AMP biotin binding sites within the aesthetasc sensillum. $a-c$, Total binding (condition 1 ) in the TZ. $a$, Cross section of CSs; $56,000 \times . b$, Cross section through proximal region of $\mathrm{TZ} ; 35,100 \times . c$, Longitudinal section in the distal region of TZ, showing branching ODSs labeled with gold; $37,800 \times . d$, Nonspecific binding (condition 2 ) in the TZ: cross section; 37,000×.e, Control binding (condition 3 ) in the TZ; $37,000 \times f f j$, Total binding (condition 1 ) in the ODS distal to the TZ; $f-i$, longitudinal sections; $j$, cross section. $f, 52,000 \times ; g, 87,100 \times ; h$, $52,000 \times ; i, 24,000 \times ; j, 40,500 \times . k$, Nonspecific binding (condition 2 ) in the ODS, approximately $100 \mu \mathrm{m}$ distal to the TZ; 40,500 $\times$. $b b$, basal body; $c r$, ciliary rootlet; $c s$, ciliary segment; ids, inner dendritic segment; ods, outer dendritic segment. Arrows in $f$ and $h$, cluster of gold particles. Scale bars, $0.1 \mu \mathrm{m}$. 

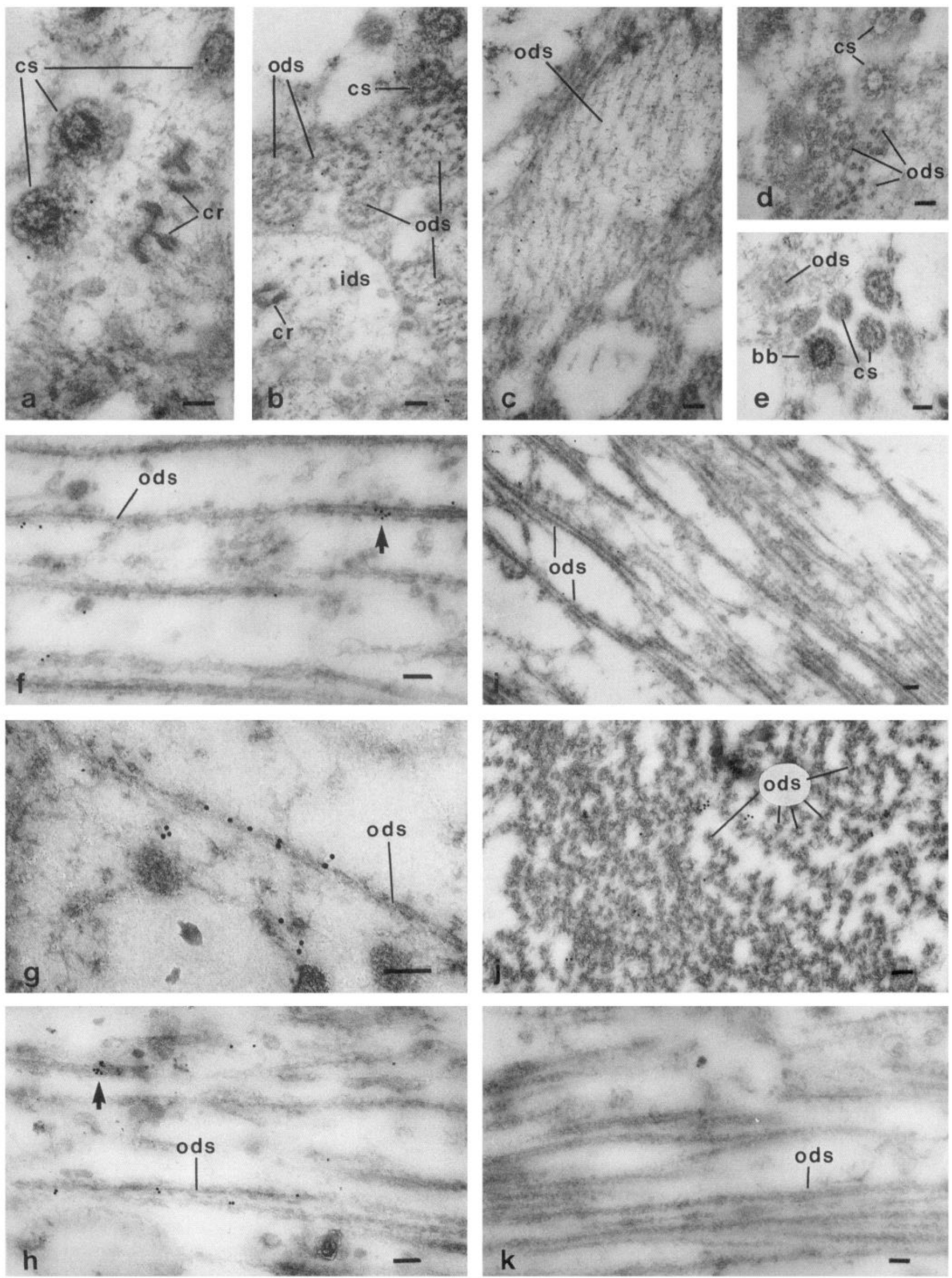


\section{DISTRIBUTION OF AMP BINDING SITES ON OLFACTORY RECEPTOR CELL DENDRITES}
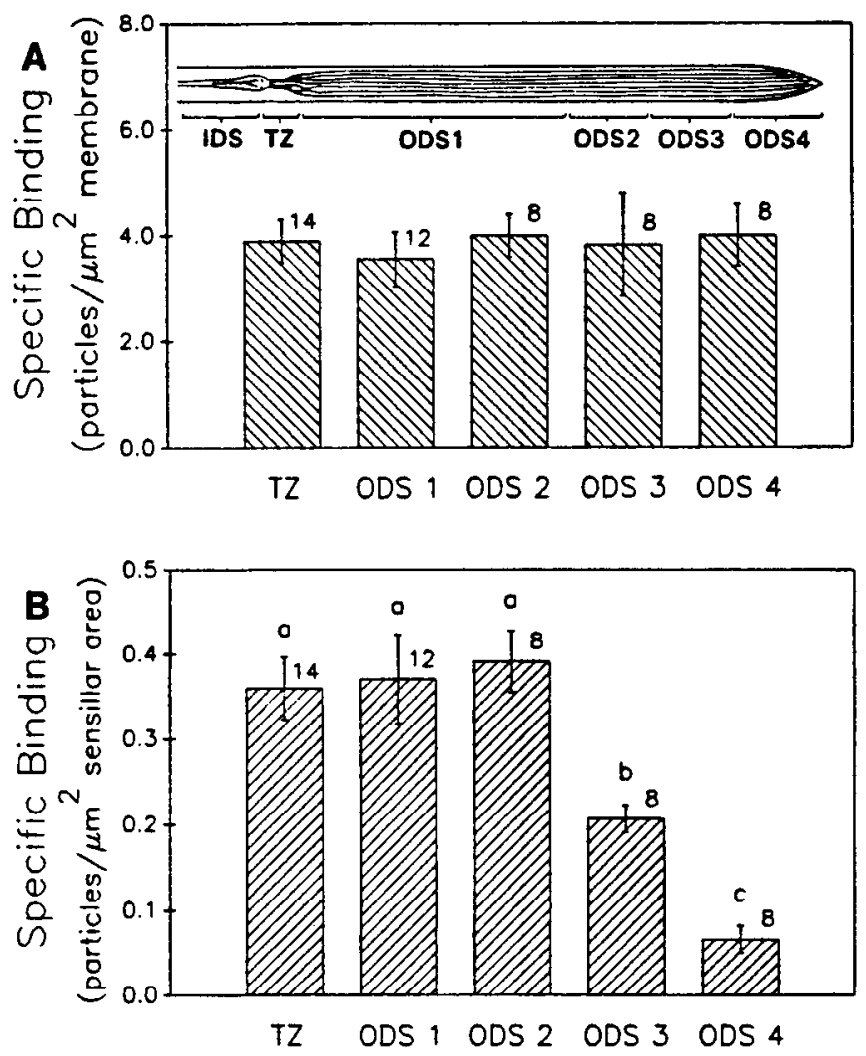

Figure 7. TEM evaluation of the distribution of 5'AMP-biotin binding sites on dendrites of olfactory receptor neurons. Specific binding is calculated as the difference between valucs for the total binding condition and the nonspecific binding condition (see Materials and Methods). Values are means \pm SEM. The number above each column represents the number of observations for each condition. Values for all regions are significantly greater than zero. The five regions of the dendrite are depicted in the inset of $A$. IDS, inner dendritic segment; $O D S$, outer dendritic segment; $T Z$, transitional zone. $A$, Number of gold particles located on olfactory receptor cell membranes per $\mu \mathrm{m}^{2}$ of dendritic membrane. No significant difference is apparent among the regions [ANOVA, $F(4,45)=0.123, P=0.97] . B$, Number of gold particles located on olfactory receptor cell membrane per $\mu \mathrm{m}^{2}$ of area within the aesthetasc sensillum. Values are means \pm SEM. There are significant differences between regions [ANOVA, $F(4,45)=10.409, P=0.0003$ ]. Regions that are significantly different from each other are labeled with different letters $(a-c)$, while responses that are not significantly different are labeled with the same letter (Student-Newman-Keuls multiple comparisons test, $\alpha$ $=0.05$ ).

binding (Fig. 5). The sum of the specific binding for the two sensillar halves was $25 \%$ lower than the specific binding for the entire sensillum, indicating a loss of this amount of membrane during the collection of tissue.

\section{TEM}

TEM immunocytochemistry using the 5'AMP-biotin probe allowed us to determine the ultrastructural localization of these 5'AMP binding sites on olfactory dendritic structures (Fig. 6). Condition 1 (total binding) exhibited an abundance of 5'AMPbiotin binding sites in the aesthetasc sensilla, as evidenced by the presence of colloidal gold (Fig. $6 a-c, f-j$ ). Most of these binding sites were associated with the plasma membrane of the dendrites of olfactory receptor neurons. Both the $\mathrm{TZ}$, which includes
CSs and initial ODS branches (Fig. $6 a-c$ ), and all distal regions of the ODS (Fig. $6 f-j$ ) displayed 5'AMP-biotin binding. CSs normally displayed single gold particles located around their periphery (Fig. $6 a, b$ ). In the ODS, individual gold particles, alone or in linear arrays, were most numerous (e.g., Fig. $6 g$ ). However, a significant number of clusters of gold particles, containing two to seven particles/cluster, were also seen (e.g., Fig. 6f,h). Nonspecific binding (condition 2) (Fig. 6e) and control binding (condition 3 ) (Fig. $6 d, k$ ) were significantly lower than total binding (condition 1) in all regions of the dendrite (ANOVA with Student-Newman-Keuls, $\alpha=0.05$ ), being $8-22 \%$ of the total binding.

Ultrastructural localization of 5'AMP-biotin binding sites permitted a quantitative analysis of the relative density of 5'AMP-specific binding sites on the various regions of the dendrite of receptor neurons (Fig. $7 A$, inset). We quantified the density of 5'AMP-biotin-specific (i.e., total minus nonspecific) binding sites both as the number of membrane-bound gold particles per $\mu \mathrm{m}^{2}$ of dendritic membrane (Fig. 7A) and as the number of membrane-bound gold particles per $\mu \mathrm{m}^{2}$ of area within the aesthetasc sensillum (Fig. $7 B$ ). These two measurements yield different values for any given sensillar region because the amount of dendritic membrane along the entire sensillum is not constant, and was estimated for the five regions (values are the means $\pm \mathrm{SEM}$, in $\mu \mathrm{m}^{2}$ for $N=10$ ): $\mathrm{TZ}=0.091 \pm 0.010$; ODS 1 $=0.104 \pm 0.010 ;$ ODS $2=0.099 \pm 0.011 ;$ ODS3 $=0.054 \pm$ $0.005 ;$ ODS $4=0.017 \pm 0.002$. Statistically significant levels of 5'AMP-biotin binding were found in all areas of the ODS and in the TZ. The density of $5^{\prime}$ AMP-biotin binding sites per $\mu \mathrm{m}^{2}$ of dendritic membrane was equal along the entire length of the ODS. The total number of 5 'AMP-biotin binding sites per area within the sensillum, however, varied along the length of the sensillum. A significantly larger number of 5'AMP-biotin binding sites occurred in the $\mathrm{TZ}$ and in the proximal $70 \%$ of the ODS (ODS1 and ODS2) than in the distal 30\% of the ODS (ODS3 and ODS4). This is because of a greater amount of membrane per sensillar area in the TZ, ODS1, and ODS2 as compared to ODS3 and ODS4.

\section{Discussion}

Chemosensory systems require ligand-receptor interactions as initial components of recognition. Binding of the ligand to the receptor leads to transduction, coding, and transport of the information to the CNS. Determination of the distribution of receptor sites is important in understanding receptor, transduction, perireceptor, and mixture interaction phenomena involved in peripheral olfactory discrimination. Visualization of olfactory receptor sites to the ultrastructural level requires high-resolution techniques that permit the preservation of the dendritic components. To achieve this end, we utilized a 5'AMP-biotin probe in conjunction with TEM and immunocytochemical techniques on olfactory receptor neurons of the spiny lobster Panulirus argus to show that 5'AMP binding sites are distributed along the entire length of the portion of the dendrites that is exposed to odorants. The density of receptors per unit area of dendritic membrane was found to be similar in the distal and proximal regions of each aesthetasc sensillum. The number of 5'AMPbiotin binding sites is lower in the distal regions of the aesthetasc sensilla as compared to the more proximal regions; this is due to the distal regions containing relatively fewer and thinner ODS branches and therefore less membrane per area within the sensillum. 
These labeled 5'AMP-biotin binding sites are either of two known types of 5'AMP binding sites: 5'AMP receptor sites that can be coupled to olfactory transduction processes (Derby et al., 1984, 1991a,b), or ectoenzymes that dephosphorylate and inactivate 5'AMP (Trapido-Rosenthal et al., 1987, 1990; Carr et al., 1990; Gleeson et al., 1991). For four reasons, we believe that many of the 5'AMP-biotin labeled sites on the dendrites and most if not all of those labeled sites on the ODS are 5'AMP receptor sites involved in transduction. First, 5'AMP-biotin binds to 5'AMP sites on olfactory cell dendrites. In biochemical studies, 5'AMP-biotin, but not biotin, was as effective as 5'AMP in competitively inhibiting the binding of ${ }^{3} \mathrm{H}-5^{\prime} \mathrm{AMP}$ to olfactory tissue in the P2 tissue fraction (Fig. 3). Second, 5'AMP-biotin excites 5'AMP-sensitive olfactory receptor neurons, as was shown in electrophysiological experiments (Fig. 4). Third, 5'AMP-biotin labeled sites are located in regions of the ODS that lack 5'ectonucleotidase/phosphatase activity (Figs. 5-7) (see Gleeson et al., 1991). 5'AMP-biotin labeled sites in the $\mathrm{TZ}$ might be either 5'-ectonucleotidase/phosphatase enzymes, 5'AMP receptor sites, or a combination of both. Biochemical studies suggest that 5'AMP receptor sites and the 5'-ectonucleotidase have roughly similar kinetics - the 5'AMP receptor has a $K_{D}$ value of $2 \mu \mathrm{M}$ (Olson et al., 1992), and the 5'-ectonucleotidase has a $K_{m}$ value of 9-33 $\mu \mathrm{M}$ (mean of $21.5 \mu \mathrm{M}$ ) (Trapido-Rosenthal et al., 1990). Their relative densities in the TZ, however, are unknown. Fourth, ${ }^{3} \mathrm{H}-5$ ' AMP-specific binding sites show tissue specificity since they occur on dendritic membrane from the aesthetasc sensilla (P2 fraction) but not on other tissue fractions from aesthetasc sensilla such as cuticle (P1 fraction) or soluble molecules (S1 fraction) (Olson et al., 1992). The location of these 5'AMP-specific binding sites specifically on dendritic membrane argues for the role of these sites in olfactory transduction.

The different distributions of the 5'AMP receptor sites and the ectoenzymes along the dendrites of the olfactory neurons may reflect their different functions. The presence of receptors along the entire length of the outer dendrite, from the $\mathrm{TZ}$ to the ODS (Figs. 6, 7), may reflect the fact that odorants probably enter the sensillum along its entire length by diffusion across its thin cuticle (Grünert and Ache, 1988; Gleeson et al., 1991, 1992). The restriction of the ectoenzymes to the $T Z$ probably refiects their importance in inactivating odorant molecules. The TZ is located near the base of the aesthetasc sensillum, where boundary layers can limit the movement of odorants to and away from the space around the sensillum (Moore et al., 1991). In addition, within the lumen of an aesthetasc sensillum, diffusional barriers are probably greatest near the $\mathrm{TZ}$ due to the relatively high density of tissue in this region. Thus, the high density of ectoenzymes in this area of restricted diffusion might help clear odorants in order to prevent excessive sensory adaptation (Gleeson et al., 1991, 1992).

Vertebrate olfactory cilia contain components of the olfactory transduction pathway (Anholt, 1991; Kinnamon and Getchell, 1991; Menco et al., 1992). Our results, in showing the presence of olfactory receptor sites on the ODS, together with other results showing the presence of $\mathrm{IP}_{3}$-gated ion channels (Fadool and Ache, 1992) and ectoenzymes (Gleeson et al., 1991, 1992) in parts of the dendrite, demonstrate that the ODS of crustaceans and the cilia of vertebrates are functionally analogous.

\section{References}

Anholt RRH (1991) Odor recognition and olfactory transduction: the new frontier. Chem Senses 16:421-427.
Asanuma N, Nomura H (1991) Cytochemical localization of adenylate cyclase activity in rat olfactory cells. J Histochem 23:83-90.

Burton PR (1992) Ultrastructural studies of microtubules and microtubule organizing centers of the vertebrate olfactory neuron. Microsc Res Tech 23:142-156.

Carr WES, Trapido-Rosenthal HG, Gleeson RA (1990) The role of degradative enzymes in chemosensory processes. Chem Senses 15: 181-190.

Derby CD, Carr WES, Ache BW (1984) Purinergic olfactory cells of crustaceans: response characteristics and similarities to internal purinergic cells of vertebrates. J Comp Physiol [A] 155:341-349.

Derby CD, Girardot M-N, Daniel PC (1991a) Responses of olfactory receptor cells of spiny lobsters to binary mixtures. I. Intensity mixture interactions. J Neurophysiol 66:112-130.

Derby CD, Girardot M-N, Daniel PC (1991b) Responses of olfactory receptor cells of spiny lobsters to binary mixtures. II. Pattern mixture interactions. J Neurophysiol 66:131-139.

Fadool DA, Ache BW (1992) Plasma membrane inositol 1,4,5-trisphosphate-activated channels mediate signal transduction in lobster olfactory receptor neurons. Neuron 9:907-918.

Fine-Levy JB, Derby CD (1992) Behavioral discrimination of binary mixtures and their components: effects of mixture interactions on coding of stimulus intensity and quality. Chem Senses 3:307-323.

Getchell TV, Heck GL, DeSimone JA, Price S (1980) The location of olfactory receptor sites. Inferences from latency measurements. Biophys J 29:397-412.

Gleeson RA, McDowell LM, Aldrich HC, Trapido-Rosenthal HG, Carr WES (1991) Localization of 5'-ectonucleotidase/phosphatase activity within the olfactory sensilla of the spiny lobster, Panulirus argus. Cell Tissue Res 265:385-391

Gleeson RA, Trapido-Rosenthal HG, McDowell LM, Aldrich HC, Carr WES(1992) Ecto-ATPase/phosphatase activity in the olfactory sensilla of the spiny lobster, Panulirus argus: localization and characterization. Cell Tissue Res 269:439-445.

Grünert U, Ache BW (1988) Ultrastructure of the aesthetasc (olfactory) sensilla of the spiny lobster, Panulirus argus. Cell Tissue Res 251:95-103.

Hallberg E, Johansson KUI, Elofsson R (1992) The aesthetasc concept: structural variations of putative olfactory receptor cell complexes in Crustacea. Microsc Res Tech 22:325-335.

Jacobson KA, Ukena D, Padgett W, Kirk KL, Daly JW (1987) Molecular probes for extracellular adenosine receptors. Biochem Pharmacol 36:1697-1707.

Keil TA (1992) Fine structure of a developing insect olfactory organ: morphogenesis of the silkworm antenna. Microsc Res Tech 22:351371.

Kinnamon SC, Getchell TV (1991) Sensory transduction in olfactory receptor neurons and gustatory receptor cells. In: Smell and taste in health and disease (Getchell TV, Doty RL, Bartoshuk LM, Snow JB, eds), pp 145-172. New York: Raven.

Klevan L, Gebeyehu G (1990) Biotinylated nucleotides for labeling and detecting DNA. Methods Enzymol 184:561-577.

Kurahashi T, Kaneto A (1991) High density cAMP-gated channels at the ciliary membrane in the olfactory receptor cell. Neuroreport 2:5-8.

Lowe G, Gold GH (1991) The spatial distributions of odorant sensitivity and odorant induced currents in salamander olfactory receptor cells. J Physiol (Lond) 442:147-168.

Menco BPM (1983) The ultrastructure of olfactory and respiratory epithelium surfaces. In: Nasal tumors in animals and man, Vol 1, Anatomy, physiology, and epidemiology (Reznik G, Stinson SF, eds), pp 44-101. Boca Raton: CRC.

Menco B, van der Wolk FM (1982) Freeze fracture characteristics of insect gustatory and olfactory sensilla. I. A comparison with vertebrate olfactory receptor cells with special reference to ciliary components. Cell Tissue Res 223:1-27.

Menco BPM, Dodd GH, Davey M, Bannister LH (1976) Presence of membrane particles in freeze-etched bovine olfactory cilia. Nature 263:597-599.

Menco BPM, Bruch RC, Dau B, Danho W (1992) Ultrastructural localization of olfactory transduction components: the $G$ protein subunit $\mathrm{G}_{\text {olf } \alpha}$ and type III adenylate cyclase. Neuron 8:441-453.

Miyamoto T, Restrepo D, Cragoe EJ Jr, Teeter JH (1992) IP $_{3}$ - and cAMP-induced responses in isolated olfactory receptor neurons from the channel catfish. J Membr Biol 127:173-183.

Moore P, Gerhardt G, Atema J (1991) Fluid dynamics and microscale 
chemical movement in the chemosensory appendages of the lobster, Homarus americanus. Chem Senses 16:663-674.

Olson KS, Trapido-Rosenthal HG, Derby CD (1992) Biochemical characterization of independent olfactory receptor sites for 5'-AMP and taurine in the spiny lobster. Brain Res 583:262-270.

Ottoson D, Shepherd GM (1967) Experiments and concepts in olfactory physiology. In: Progress in brain research, Vol 23 (Zotterman Y, ed), pp 83-138. New York: Elsevier.

Spencer M, Linberg KA (1986) Ultrastructure of aesthetasc innervation and external morphology of the lateral antennule setae of the spiny lobster Panulirus interruptus (Randall). Cell Tissue Res 245: 65-80.

Stiles GL (1986) Adenosine receptors: structure, function and regulation. Trends Pharmacol Science 7:486-490.
Tierney AJ, Thompson CS, Dunham DW (1986) Fine structure of aesthetasc chemoreceptors in the crayfish Orconectes propinquus. Can J Zool 64:392-399.

Trapido-Rosenthal HG, Carr WES, Gleeson RA (1987) Biochemistry of an olfactory purinergic system: dephosphorylation of excitatory nucleotides and uptake of adenosine. J Neurochem 49:1174-1182.

Trapido-Rosenthal HG, Carr WES, Gleeson RA (1990) Ectonucleotidase activities associated with the olfactory organ of the spiny lobster. J Neurochem 55:88-96.

Zufall F, Hatt H (1991) Dual activation of a sex pheromone-dependent ion channel from insect olfactory dendrites by protein kinase $\mathrm{C}$ activators and cyclic GMP. Proc Natl Acad Sci USA 88:8520-8524. 